\title{
Article
}

\section{Ferrocene-Based Nonphosphorus Copolymer: Synthesis, High-Charring Mechanism, and Its Application in Fire Retardant Epoxy Resin}

Liao, Dui-Jun, Xu, Qi-Kui, McCabe, Richard W., Babu, Heeralal Vignesh, Hu, Xiao-Ping, Pan, Ning, Wang, De-Yi and Hull, T Richard Available at https://clok.uclan.ac.uk/20506/

Liao, Dui-Jun, Xu, Qi-Kui, McCabe, Richard W., Babu, Heeralal Vignesh, Hu, Xiao-Ping, Pan, Ning, Wang, De-Yi and Hull, T Richard orcid iconORCID: 00000002-7970-4208 (2017) Ferrocene-Based Nonphosphorus Copolymer: Synthesis, High-Charring Mechanism, and Its Application in Fire Retardant Epoxy Resin. Industrial \& Engineering Chemistry Research, 56 (44). pp. 12639-12643. ISSN 1520-5045

It is advisable to refer to the publisher's version if you intend to cite from the work. http://dx.doi.org/10.1021/acs.iecr.7b02980

For more information about UCLan's research in this area go to http://www.uclan.ac.uk/researchgroups/ and search for < name of research Group>.

For information about Research generally at UCLan please go to http://www.uclan.ac.uk/research/

All outputs in CLoK are protected by Intellectual Property Rights law, including Copyright law. Copyright, IPR and Moral Rights for the works on this site are retained by the individual authors and/or other copyright owners. Terms and conditions for use of this material are defined in the policies page. 


\section{Ferrocene-Based Non-phosphorus Copolymer: Synthesis, High-charring Mechanism and Its Application in fire retardant Epoxy Resin}

Dui-Jun Liao ${ }^{\dagger}$, Qi-Kui Xü ${ }^{\dagger}$, Richard W. McCabe ${ }^{\ddagger}$,Heeralal Vignesh Babu ${ }^{\Uparrow}$, Xiao-Ping $H_{u^{\dagger *}}$, Ning Pan ${ }^{\xi}$, De-Yi Wang, T. Richard Hull ${ }^{\text {* }^{*}}$

${ }^{\dagger}$ School of materials Science and Engineering, Southwest University of Science and Technology, Mianyang 621010, P.R. China

${ }^{\ddagger}$ Centre for Fire and Hazards Science, University of Central Lancashire, Preston PR1 2HE, UK.

"IMDEA Materials Institute, C/Eric Kandel, 2, 28906 Getafe, Madrid, Spain ${ }^{\xi}$ Fundamental Science on Nuclear Wastes and Environmental Safety Laboratory, Southwest University of Science and Technology, Mianyang 621010, P. R. China

* Corresponding authors: Prof. Xiao Ping Hu; Prof. T. Richard Hull E-mail addresses: huxiaoping@swut.edu.cn (Xiao Ping Hu); trhull@uclan.ac.uk 


\section{Additional Supporting Data}

\section{Table caption}

Table S1. Chemical structures of pyrolysis compounds for PDPFDE at $700{ }^{\circ} \mathrm{C}$ under

$\mathrm{N}_{2}$

\section{Figure captions}

Figure S1. FTIR spectrum of DAF

Figure S2. ${ }^{1} \mathrm{H}$ NMR spectrum of DAF.

Figure S3. ${ }^{13} \mathrm{C}$ NMR spectrum of DAF.

Figure S4. ${ }^{1} \mathrm{H}$ NMR spectrum of DCF.

Figure S5. GPC curve of PDPFDE.

Figure S6. DSC curve of PDPFDE in $\mathrm{N}_{2}$ atmosphere.

Figure S7. The SEM image of the char residue of PDPFDE under nitrogen at $700{ }^{\circ} \mathrm{C}$ in muffle furnace for $30 \mathrm{~min}$. 
Table S1. Chemical structures of pyrolysis compounds for PDPFDE at $700{ }^{\circ} \mathrm{C}$ under $\mathrm{N}_{2}$

\begin{tabular}{|c|c|c|c|c|}
\hline Peak & $\mathbf{t}_{\mathrm{R}}(\mathrm{min})$ & Name of compounds & molecular formula & $\begin{array}{c}\text { M.W } \\
\text { (g/mol) }\end{array}$ \\
\hline 1 & 1.52 & carbon dioxide & $\mathrm{CO}_{2}$ & 44 \\
\hline 2 & 1.89 & cyclopentadiene & & 66 \\
\hline 3 & 2.51 & 1-methyl-cyclopentadiene & & 80 \\
\hline 4 & 2.74 & benzene & & 78 \\
\hline 5 & 4.46 & toluene & & 92 \\
\hline 6 & 5.41 & 2-ethylacridine & & 207 \\
\hline 7 & 6.32 & ethylbenzene & & 106 \\
\hline 8 & 6.94 & benzenemethanimine & & 105 \\
\hline 9 & 8.47 & 1-actylcyclopentadiene & & 108 \\
\hline 10 & 9.48 & indane & & 118 \\
\hline 11 & 9.79 & indene & & 116 \\
\hline 12 & 11.68 & 1-methylindene & & 130 \\
\hline 13 & 12.11 & naphthalene & & 128 \\
\hline 14 & 13.66 & 2,6-dimethylnaphthalene & & 156 \\
\hline 15 & 14.07 & ferrrocene & 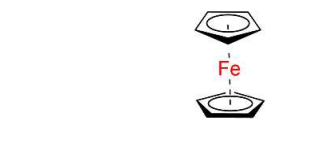 & 186 \\
\hline 16 & 14.89 & biphenyl & & 154 \\
\hline
\end{tabular}




\begin{tabular}{|c|c|c|c|c|}
\hline 17 & 15.17 & diphenylmethane & & 168 \\
\hline 18 & 15.30 & 1-naphthalene-carbonitrile & & 153 \\
\hline 19 & 16.66 & bibenzyl & & 182 \\
\hline 20 & 17.49 & 1H-phenalene & & 166 \\
\hline 21 & 18.72 & 1-acetyl ferrocene & ise & 228 \\
\hline 22 & 18.90 & (E)-stilbene & & 180 \\
\hline 23 & 19.28 & $\begin{array}{c}\text { 1,4-dimethyl-7-(1-methylethyl) } \\
\text { azulene }\end{array}$ & & 198 \\
\hline 24 & 20.03 & $\begin{array}{c}\text { 1,1',1”-(1-ethanyl-2-ylidene) } \\
\text { tris-benzene }\end{array}$ & & 258 \\
\hline 25 & 20.60 & 2,2'-diphenylethylamne & & 196 \\
\hline 26 & 22.09 & 1,1'-diacetyl-ferrocene & 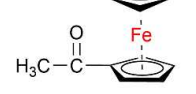 & 270 \\
\hline 27 & 22.39 & Iron & $\mathrm{Fe}$ & 56 \\
\hline 28 & 23.99 & 3-methyl terphenyl & & 244 \\
\hline
\end{tabular}




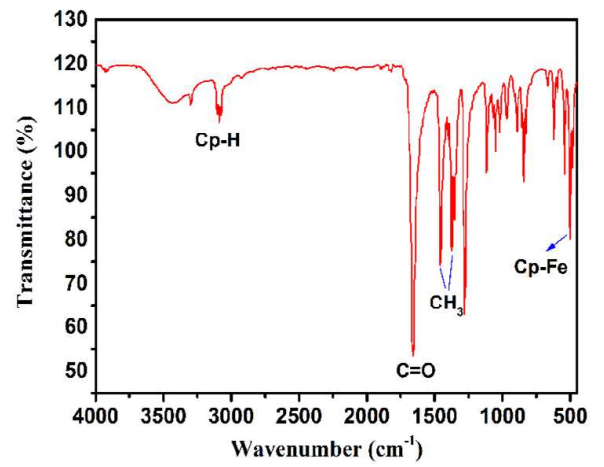

Figure S1. FTIR spectrum of DAF

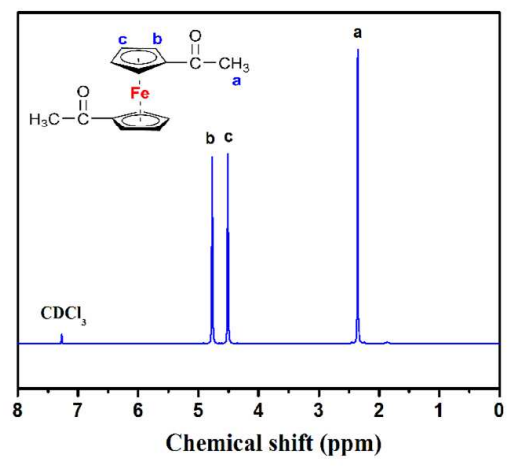

Figure S2. ${ }^{1} \mathrm{H}$ NMR spectrum of DAF

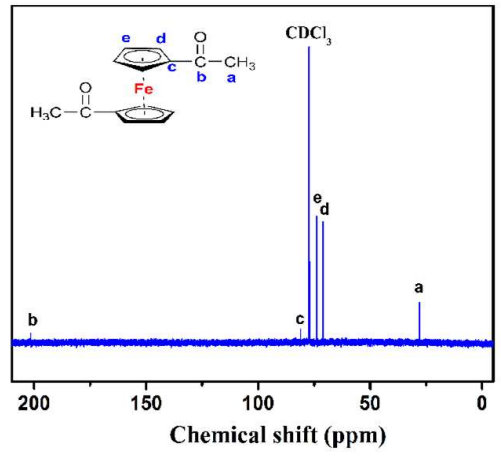

Figure S3. ${ }^{13} \mathrm{C}$ NMR spectrum of DAF 


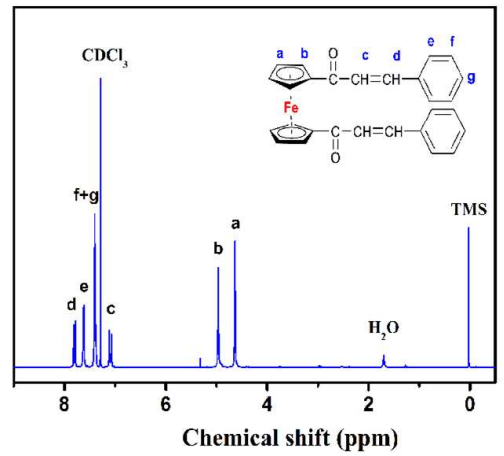

Figure S4. ${ }^{1} \mathrm{H}$ NMR spectrum of DCF

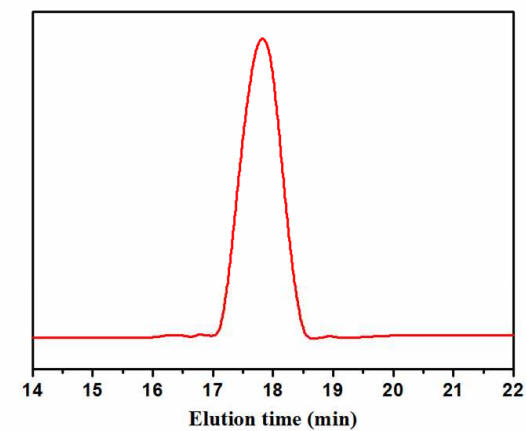

Figure S5. GPC curve of PDPFDE.

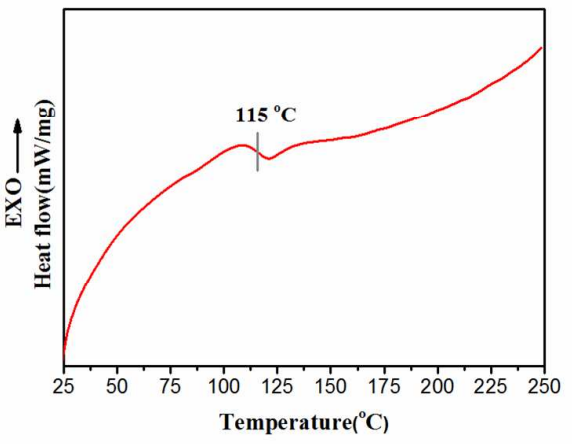

Figure S6. DSC curve of PDPFDE in $\mathrm{N}_{2}$ atmosphere. 


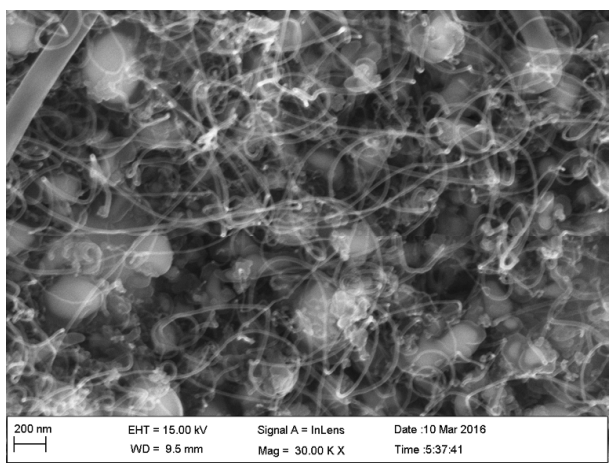

Figure S7. The SEM image of the char residue of PDPFDE under nitrogen at $700^{\circ} \mathrm{C}$ in muffle furnace for $30 \mathrm{~min}$.

The Figure S7 represents the SEM image of the char residue of PDPFDE under nitrogen at $700^{\circ} \mathrm{C}$ in muffle furnace for $30 \mathrm{~min}$. Based on the SEM image, we can clearly see the many nanowires existing in the char residue. However, the investigation of the detailed component and structure of the nanowires needs further study in the future. 